\title{
İlişkiselliğin İki Yönü: Şehir ve Beden ${ }^{1}$
}

\author{
Yaylagül Ceran Karataş \\ Medeniyet Üniversitesi
}

\section{Öz}

Şehir ve beden arasındaki ontolojik ve estetik bă̆g, tarihsel süreç içinde özellikle modern batıda bilim, ekonomi, politika ve sanat alanlarında yaşanan büyük değişimlerle mekanik ve anlamsız bir yapıya dönüşmüştür. Mimarların ve şehir plancılarının "yeni şehir" tasarımlarında bu dönüşüm açıkça görülmektedir. Sennett'in de belirttiği gibi, kutsal, gelenek ve modernite arasındaki çatışmada' 'genel beden dili şehir mekanına tercüme edildiğinde tuhaf bir yazgıyla karşı karşıya kalınmıştır.' Bu yazgı bedenin nasıl algılandı̆̆ılyla bă̆lantılı olarak şehirlerin nasıl kurgulandığııın da bir göstergesi olmuştur. Bu çerçevede 'İlişkiselliğin iki yönü: Şehir ve Beden' adl çalışmamızda Antikçă̆ Atina'sl, Ortaçă̆ Roma'sl, Rönesans ve sonrası Venedik'i, Yeniçă̆ Paris'i ve içinde bulunulan yüzyılda modern ve postmodern şehirleri inceleyerek 20.yy'da insana-bedene ilişkin kabullerin şehirlerin yapılandırılması konusunda nasıl bir imaj oluşturduğunu tartışmaya açacağız. Buradaki temel kabulümüz 'şehirler, mekanik-statik mekanlar değil, tıpkı insanlar gibi ontoantropolojik yapıy temsil eden dinamik mekanlardır.' Bu yargıyı felsefi antropoloji ve şehir planlama yaklaşımları çerçevesinde günümüz küresel şehirlerin arka planında yer alan beden imajına dair sorularımızı şehir ve beden ilişkisinde tartışmaya açarak temellendireceğiz.

Anahtar Kelimeler: Beden, Şehir, Özgürlük, Felsefi Antropoloji, Şehir Sosyoloji-Planlaması

\footnotetext{
${ }^{1}$ Bu yazı, Felsefe ve Şehir Kongresinde "Şehir: Sahne, Vitrin, Sokak, Beden ve Özgürlük" (2012) başlıklı bildirinin genişletilmiş ve değiştirilmiş halidir.

idealkent (c) Kent Araştırmaları Dergisi (Journal of Urban Studies) 


\title{
Two Sides of Relationality: Body and City
}

\author{
Yaylagül Ceran Karataş \\ Medeniyet University
}

\begin{abstract}
In the history of the western modern era, which faced with drastic changes in science, economy, politics, and art perspectives, ontological and an aesthetical correlation between city and body turn into a mechanic and meaningless structure. This changing is clearly seen "new city designs" of architects and city planners. Conflicted between sacred, tradition and modernity creates strange meaning about body and city relations as Sennett said: "there is a strange destiny when body language has been translated city space". This destiny signified that perceiving body is how the city is perceived. In this article, Two Sides of Relationality: Body and City, we discuss how body images translate into city plans while inquiring the Ancient Athen, the Middle Age Roma, the Renaissance Venice, the New Age Paris, and Modern-Postmodern cities in the context of 20th century. Our argument is "cities have an onto-anthropologic dynamic space rather than mechanic-static spaces". We bring this idea up for discussion via philosophical anthropology and city planning theories in terms of understanding of body imaginations which underlies background of global cities.
\end{abstract}

Keywords: Body, City, Freedom, Philosophical Anthropology, City Sociology-Planning 


\section{Giriş}

Protagoras'ın "insan her şeyin, varolan şeylerin varolduklarının ve varolmayan şeylerin varolmadıklarının ölçüsüdür" (Zeller, 2001, s. 102) kabulü şehirlerle beden arasındaki ilişkinin çağımız soruları açısından ve özellikle bağlarına-bağlamına yabancılaşan insanın anlaşılmasında ontolojikmetafizik bir referans olarak alınmalıdır. Bunun yanı sıra insan bedeni hakkındaki düşüncelerin tarihi incelendiğinde içinde yaşanılan dönemin ticaretiyle ve teknolojisiyle ilişkili olarak açıklama modeli geliştirildiğini söyleyebiliriz. Bu noktada, Mumford, özelde antik şehirlerde ve genelde dünya şehirlerinde de gözlemlenen faaliyetler sınıflandırıldığında iki temel insan faaliyetinin şehir hakkında araştırma yapan herkes tarafından mutlaka akılda tutulması gerektiğini söyler. Bunlardan ilki, her yerde görülen fakat özellikle şehrin fiziksel yapısınca biçimlendirilen ve geliştirilen insan faaliyetleridir. İkincisi ise şehrin tarihi bağlamı ve biricikliği çerçevesinde şehre özgü ve şehir için geliştirilen üretim faaliyetleridir (Mumford, 1989, s. 99). İlk faaliyet, insanın mekan olarak şehri kurduğu, kendi için yaşanılır bir mekana dönüştürdüğü ve onunla toplumsallaştığ 1 faaliyettir ki, hem dini hem etik hem de estetik ritüelleri, seremonileri, sanatı ve ibadetleri içerir. Bu faaliyet ile şehrin ve kültürün sınırları bedenin ve eylemin sınırlarıyla birleşir. İkinci faaliyet ise bizatihi şehrin ve insan faaliyetlerinin sürekliliği için gerekli olan şehrin fiziki ve tarihi yapısıyla bağlantılı olarak şekil alan faaliyetlerdir ki, ticareti, siyaseti ve toplumsal sınıfları içerir. Bu faaliyetler şehrin bireysel ya/ ya da toplumsal mekan ve zamanla kurulan ilişkilerde biricikleştirilir. Bireysel ve toplumsal mekanda 'o mekanı' düşünen zihin ve bu düşünme eyleminin kendisi ‘o mekan'da ve 'o şimdi'de varlık kazanır. Böylece hem mikro hem makro mekan olarak şehir ne önceden kurulmuş, tamamlanmış bir sahnedir ne de sadece üretim ilişkilerinin sonucudur. Şehir, bütün yönleriyle insanın 'kendisini' temsil eden bir 'sürekli şimdide varolan' mekandır. Bu çerçevede şunu söylebiliriz, Mumford'un sınıflandırdığı iki temel faaliyet aç1sindan şehir tarihinin üç önemli itici unsuru bulunmaktadır: Ekonomi, Siyaset ve Kültür.

Şehir sosyologu Park'a göre 'şehir, bir ruh durumu, bir gelenek-görenek toplamı ve bu göreneklerden miras aldığımız, bu geleneklerle aktardığımız örgütlü tutumlar ve duygular toplamıdır. Şehir sadece fiziksel bir mekanizma ve sunî bir yapı değildir, onu inşa eden bireylerin hayatlarını içeren doğanın ve kültürün ürünüdür.' (Park \& Burgess, 1984, s. 1). Wirth 
Şehir Sosyolojisi Bibliyografisi adlı makalesinde bir şehir hakkında 11 ayrı kategoride araştırma yapılabilileceğini bildirir (Park \& Burgess, 1984, s. 163). Bu kategoriler, bir şehrin fiziksel-sosyal ve kültürel yapısını incelerken onu inşa eden insanın bedensel bütünlüğü, içinde bulunduğu bilinçsel süreçleri ve toplumsal yönü de o şehrin anlaşılmasını ve anlatılmasını etkiler, belirler.

Antik Yunan ve genel olarak Batı Ortaçağı için şehirler bir yanıyla, doğal ve toplumsal mekanı düzenlemek üzere insanın kendi eliyle meydana getirdiği birer "tasarım", "varlık evidir", bir yanıla da toplumsal hayatı yönlendiren, biçimlendiren eylemlerin somut bir göstergesi olan "res publica"dır. Başka bir ifadeyle, şehir insanın doğal mekanı sosyal ve fizikî inşa çabasının 'ürünü' ve dolayısıyla kendisini seyrettiği aynadır. John of Salisbury, "bir şehrin formu insan bedenine benzer; şehrin sarayını ya da kutsal mekanını baş; merkezini mide ve evlerini de el ve ayak temsil eder. İnsanlar bu nedenle kutsal mekanlarda yavaşlarlar (rasyonellik ön plana çıkar) ve çarşıda hızlanırlar (tutku ve duygusallık ön plana çıkar)" (Sennett, Ten ve Taş, 2002, s. 18) analojisi şehir bedenin izdüşümüdür; mekanlarn insanlarm kendi suretine uygun olarak tutarl ve bütün hale getirilen şehir, toplumsal süreklilik açısından bir iktidar merkezidir yargısını da içermektedir. Tarihsel süreç dikkate alındığında, Modern öncesi dönemdeki temel ayrım genel olarak insanın "vücut olarak varolma" ile "beden sahibi olma" arasındaki "iradî" eyleminde ortaya çıkmaktadır ve bu ayrım şehir ve beden arasındaki ilişkiyi "anlam" bağlamında yeniden düşünmeye davet etmektedir. İnsan doğasının bir yandan fiziksel mekanın biçimlendirilmesinde ve mekandaki faaliyetlerin belirlenmesinde bir yandan da mekanın sosyal yapılandırılmasında ve simgeleştirilmesinde referans olarak kullanıldığı görülmüştür. Şehir birey-beden olarak insanın tarih ve mekan duyusuyla biçimlendirdiği, dönüştürdüğü ve aynı zamanda refleksiyonla kendini de inşa ettiği 'yer'-'mekan'dır. Burada insan birey olarak hayatının mekansallaştığ anlam bağlamlarında geçmişte, şimdide-birleşik anlarda ve gelecekte, tarihin üç boyutu, içinde yeniden kurar. Grek şair Alcaeus bir şiirinde

'ne evlerin iyi yapılmış çatıları

ne iyi örülmüş duvarlar

ne kanallar ne de tershaneler

şehri meydana getirir,

fakat insan

bu imkanları kullanarak şehri meydana getirir' 
diyerek, şehrin yalnızca insanın içine doğduğu doğal ve/veya hazırlanmış bir 'sahne' olmadığını insan tarafından yine insan için kurulduğunu çok sarih bir ifadeyle ortaya koymaktadır.

Caddeleri, sokakları ve sembol yapılarıyla kendi başına kompleks toplumsal yapının güçlü bir göstergesi ve insanın "varlık evi" olan şehirler, simgeler bütünü olarak hem ontolojik hem de metafizik anlamda "eylem" mekanlarıdır (Lynch, 1960). Aslında şehir Calvino'nun dediği gibi her kent biçimini karşısında durduğu çölden alır (Calvino, 2009, s. 68). Kollektif olarak şehirler üretilirken-kurulurken aynı zamanda insan da benliğini aşarak kendini kurar, inşa edilen mekana kendini katar. Şöyle ki, şehirlerin nasıl olması gerektiğine dair plan ve projeler bir yandan da insanın varlık, bilme ve eyleme olanaklarına bağlı olarak, insanın kendisini kim olarak görmek istediğini de açıklayan projelerdir. J. Jacobs The Economy of Cities adlı kitabında şehirlerin konumları ya da sahip oldukları ekonomik kaynaklar aracılığıyla açıklanamayacağını, onu kuran insanlar tarafından bir 'varolma' projesi olarak anlaşılıp açıklanabileceğini söyler (Jacobs, 1969, s. 141). Başka bir ifadeyle, nasıl bir şehir istediğimiz sorusu nasıl bir insan olmak istediğimiz, nasıl bir doğada yaşamak istediğimiz, nasıl bir estetik duyuşa sahip olduğumuz/olmak istediğimiz ve nasıl bir toplumsal örgütlenme planladığımız sorularıla birlikte şekillenmektedir (David, 2013, s. 44).

İnsanın 'insan olma' başarısı, kendi eliyle kurduğu ve eyleminin mekanı olan şehrin 'bizatihi kendinde' varlık amacının sorulması, neliğinin araştırılması ve doğal olandan farklılaş(tırıl)ması oluş, zaman ve mekan ilişkisi bağlamında hem ekonomi-politik hem de felsefi antropoloji açısından dinamik bir tartışma zemini oluşturur.

\section{Yöntem}

Bu çalışmamız şehir ve beden arasındaki ilişkide iki farklı disiplini (felsefi antropolojiyi ve şehir planlamayı (sosyal ve fizikî)) insanın 'anlam arayışı'nın ortak paydası olarak yorumlama denemesidir. Bu bağlamda M. Scheler, (1874-1928) insan felsefesi ya da felsefî antropoloji çalışmalarını Batı Felsefe geleneğinde ortaya çıkan birçok farklı yaklaşımı yine aynı gelenek içinde kalarak fakat farklı kabullerle temellendirilen dört ayrı tarihsel yaklaşım çerçevesinde sınıflandırmıştır. Teolojiye, felsefeye ve bilime ait temel antropoloji yaklaşımlarını tespit eden Scheler, her yaklaşımda ortaya çıan insan düşüncesini bütünsel bir çerçevede ele alarak felsefî 
antropolojinin sınırlarını belirlemiştir. Max Scheler'in felsefi antropoloji sinıflandırmasıyla Richard Sennett'in şehir planında insan bedeninin izdüşümlerini takip eden yaklaşımını; Chicago Okulunun temsilcilerinden Louis Wirth ve Robert E. Park'ın insan davranışları ve şehrin kuruluşu arasındaki ilişkiyi temele alan toplumbilimsel planlama çalışmalarını ve Mumford'un şehrin sosyal ve fiziki planlama anlayışında modern ve postmodern yorumlarıyla bağlantı kurarak şehir ve felsefenin 'şehir ve beden' ilişkiselliğinin imkanını temellendirmeye çalışacağız. Başka bir ifadeyle ve daha kuşatıcı bir bakış açısıyla yaşadığı mekanı anlamlandıran ve ona yeni bir kategori yükleyen insanı, şehrin ve şehrin mekanları arasında varoluşunu ve de değerler üretmesini felsefî antropoloji ve şehir planlama ışı̆̆ında fenomenoloji ve fenomonolojik hermenötik bağlamında yeniden anlamaya çalışacağız.

\section{Şehir ve Beden: Atina, Roma, Venedik ve Paris}

\section{Şehir ve Beden}

Şehir ve beden arasında dönüştürücü nitelikte çift yönlü bir ilişki vardır. Bu ilişki bir yönüyle bedeni, duyguları ve düşünceleri açısından insanı mekana bağlı ve mekanda sınırlandırılmış kılarken, bir yönüyle de şehirlerin bedenin izdüşümü olarak kurulmasını mümkün kılar. Burada insan beden formuna uygun olarak imar ettiği birçok şehrin cadde, sokak ve vitrinlerinde hem bireysel hem de toplumsal düzlemde kendini gerçekleştirme alanları oluşturmuştur. Başka bir ifadeyle, bu çift yönlü ilişki tarihin belirli dönüm noktalarında incelendiğinde inşa edilen şehirlerin farklı beden anlayışlarının ve farklı kimliklerin dönüşümlerinin "teni-mekanı” oldukları gözlemlenmektedir. Örneğin, Atina'nın, Roma'nın, Venedik'in ve Paris'in tarih içinde temsil ettikleri imajlar ve hem modern hem de postmodern şehir algısıyla dönüşen şehir imajları ekonomik, politik, kültürel ve dinî açıdan çatışmaların, savaşların ya da ortaklıkların yanı sıra özellikle insan-beden anlayışının şehirde yansıyan yönlerini ve değişimini de gözler önüne sermektedir.

Bu çerçevede felsefi antropolojinin 'Logos insanı', 'tanrısal insan', 'biyolojik insan' ve 'kaotik insan' anlayışlarında ortaya (Scheler, 1968) çıkan soyut beden imajı, Hegel'in ifadesiyle tinin tarih içinde kendini gerçekleştirmesi gibi tarihin farklı süreçlerinde somutlaşmış ve şehrin teni olmuştur tıpkı Atina, Roma, Venedik, Paris ve çağımızın modern-postmodern şehirleri gibi. Şehir ve beden ilişkisi anlam arayışı çerçevesinde süreç 
içinde ve anlamın neliği açısından değişime uğramıştır. İnsanın kozmozla kurduğu bağ şehrin fiziki ve sosyal yapısını belirlemiş, etkilemiş ve dönüştürmüştür. Bu çerçevede felsefi antropolojinin dört insan formunun ('Logos insanı', 'tanrısal insan', 'biyolojik insan' ve 'kaotik insan') şehir planlama teorilerinin kabulleriyle eşleştirerek dört farklı şehir ve anlam ilişkisi kurabiliriz.

\section{"Logos İnsanı" ve Açık Şehir}

Felsefi antropolojinin antik yunan geleneğinde ön görülen doğa ve akıl kabulleri çerçevesinde "Logos İnsanı" anlayışı Atina ve pagan Roma şehirlerinde iktidar merkezi logosa kulak vererek biçimlenen akıl, etik ve estetik değer imajı olarak çıplaklıkla tanımlanan erkek (yurttaş) bedenine dönüşmüştür ve bu anlayış mekan olarak agoralarda ve pazarlarda başat imge olmuştur.

Antikçağ Atina'sının formu ticari ilişkilerin yanı sıra özellikle insan ile şehir arasında kurulan analoji vücut ısısının, sesin ve bedenin durumuna göre belirlenmiştir. Perikles Cenaze Töreni Söylevi'nde Atina Şehrini şöyle tanımlar: “... Atina şehri Helen dünyasının bir okuludur. Burada bana yaşam uğraşlarının bütün biçimlerinde, hem de incelikle birleşmiş büyük bir beceriklilikle herkes kendi kişiliğini, kendi vücudunu her şeye gücü yetecek bir duruma koyuyor gibi geliyor." (Şenel, 1995, s. 139) Buna göre "gösterme", "teşhir etme" ve "açığa çıkarma" üzerindeki vurgu bilme eyleminde gözün ve kulakların gücünü önceleyen Herakleitosçu bilgi ve varlık anlayışını merkeze alarak (Herakleitos, 2009, s. 141) Atina'nın şehir ve mimari yapısına damgasını vurmuştur. Örneğin, "Perikles'in döneminin en büyük binası olan Parthenon tapinağ $\breve{l}$, şehrin her yerinden görülebilsin diye bir tepenin üzerine yapılmıştır. Atinalıların inşa ettikleri siyaset mekanlarında, en başta da bütün yurttaşlardan oluşan meclisin toplandiğı Pnykes tepesi üzerinde inşa edilmiş olan tiyatroda kalabalı̆̆ı örgütlenmesi ve oylama kurallarının belirlenmesinde bireylerin ya da küçük gruplarn herkesin göz önünde oy kullanmalarn istenmiştir." (Sennett, Ten ve Taş, 2002, s. 27). 

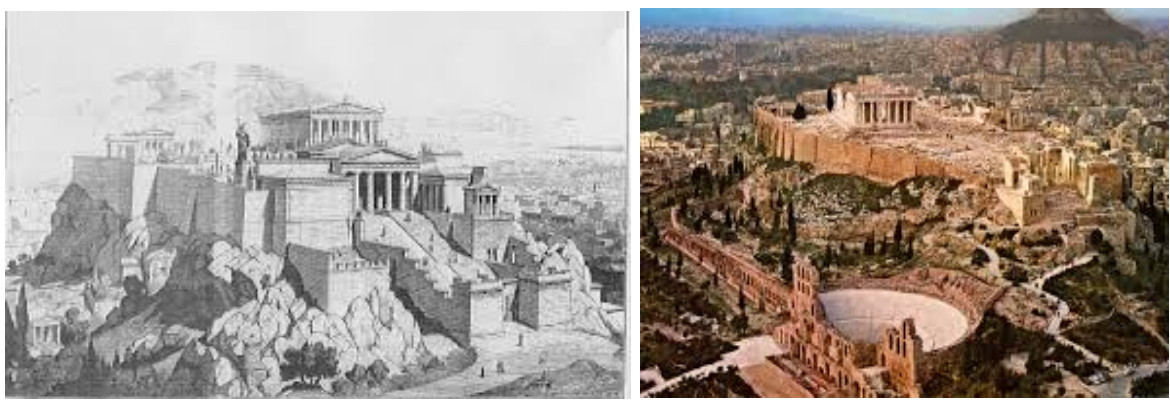

Pnykes Tepesi, (Kaynak: Sennett, 2002)

Atinalılar için çıplaklıkta somutlaşan gösterme, açı̆̆a çıkarma, duyurma eylemleri kendilerini evlerinde (oikos) gibi güvende hissettiklerinin, şehirlerine aşık olduklarının ve ona kendilerini açtıklarının, demokrasiye ve iktidara güvendiklerinin simgesi ve ait oldukları sınıfın temsili olarak kabul edilmiştir. Ayrıca Atina'daki “çıplaklık” düşüncesinin temelinde "vücut 1sısı" anlayışı yer almaktaydı ve farklı sıcaklıklara sahip vücutlar için farklı haklar ve farklı şehir mekanları tasarlanmıştı. Vücut 1sısına dayalı bu fizyoloji anlayışı etik ve estetik değerleri de belirlemekteydi (Sennett, Ten ve Taş, 2002, s. 35). Dişil, soğuk, pasif (dinleyen, oturan) olan ve zayıftan başlayan eril, sıcak, güçlü ve girişkene doğru yükselen hiyerarşik bir değer skalası oluşturulmuştu. Bu hiyerarşide en altta soğuk ve bu nedenle hitabet yeteneği olmayan kadınların ve kölelerin bedeni (erkek bile olsa) ile en üstte sıcak ve bu nedenle meclisteki tartışmalarda da belagat ile vücut isısı iyice artan yurttaş erkeklerin bedeni bulunmaktadır (Sennett, Ten ve Taş, 2002, s. 36). Bu dönemde kadın bedeninin hem fizyolojisi hem de toplumsal rolleri açısından erkeklere göre daha soğuk ve karanlık olduğu kabûlü hakimdir. Bu nedenle kadınlar vücutlarını örtmek zorunda bırakılmışlar ve agorada çıplak olarak dolaşmalarına izin verilmemiştir. Bu soğuk vücutlulara (kadınlara), şehirde en uygun mekan kapalı ve 1şıksız evler ve en uygun toplumsal rol ise ev işleri ve çocukların fiziksel bakımıydı. Vücut ısıları yüksek olan erkekler ise bulundukları toplumsal statüye göre yarı çıplak olarak dolaşıp, yüksek sütunlarla ve 1şı̆̆ı farklı açılardan alan toplumsal alanlarda (stoalarda) "görülebilir-görebilirlerdi." Bedeni çıplaklıkla, çıplaklığı da vücut ısısıyla tanımlayan bu fizyolojik ilkenin temelinde insanların logosa kulak verdiğinde ve logosu dile getirdiklerinde vücut ısılarının ve bununla birlikte harekete geçme arzularının ve kavrayış güçlerinin yükseldiği böylece de şehrin onurunun yüceltildiği düşüncesi yer almaktadır. 
Herakleitos'un "parlak, en sicak ve kuru olan ruh, en iyi ve en bilgedir" (Herakleitos, 2009, s. 273) diyerek vücut 1sısının bilgelikte ve temsil gücünde önemine dair vurgusu hem şehrin planlanmasında hem de toplumsal rollerin sınıflandırılmasında belirleyici olmuştur.

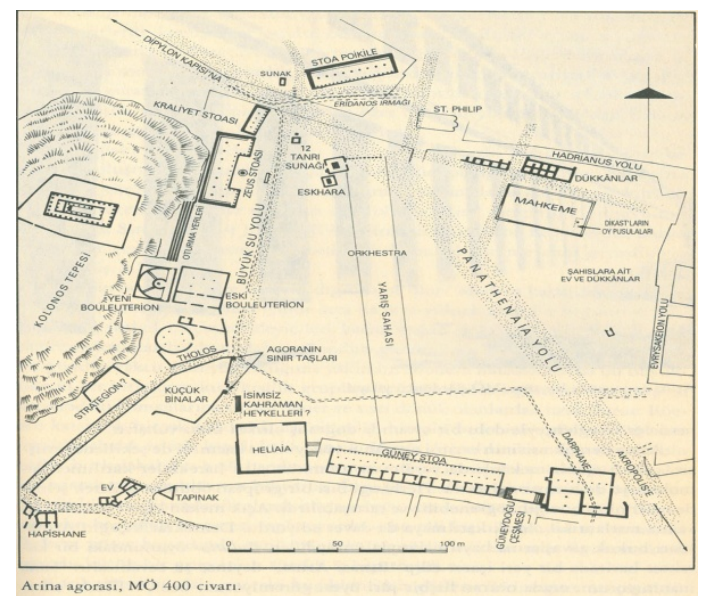

Atina Agorası MÖ 400 civarı, (Kaynak: Sennett, 2002 s. 45)

Antikçağ için şehir aynı zamanda "Devlet"ti, meclisi, yurttaşları, ticareti ve kültürüyle yönetici erkin iktidar mekanıydı. Özellikle Platon Devlet kitabında ve Aristoteles Politika'da şehrin kurucu unsurlarını sıralarken coğrafi sınırlardan başlanıp, nüfusuna, pazarının formuna, toplumsal sinıflarına ve yönetim şekline kadar ayrıntılı olarak açıklanmıştır. Mesela Platon'un şehri (polis) 5040 kişiden oluşan, insan vücudu örnek alınarak sinıflara ayrılmış, bir tepe üzerine kurulu ve aristokrasi ya da monarşi ile filozof kralın yönettiği bir şehirdir. (Platon, 2000) Aristoteles'in şehri ise farklı insan gruplarınca kurulan ve çevreden merkeze doğru gittikçe daralan birliklerin biraraya gelmesiyle oluşan bir şehirdir. (Aristoteles, 2013) Her iki filozof için esas olan şehrin fiziki sınırlarının, ekonomisinin ve politikasının ötesinde şehri kuran insan topluluklarının ontolojik ve etik değerleridir.

Platon ve Aristoteles'in theorialarındaki ideal şehirlerinde ve Perikles'in gerçek Atina'sında şehrin fiziki yapısı ve toplumsal örgütlenişi insan anatomisinin bir kopyası değildi. Fakat vücut ısısında temelini bulan insan bedeninin ve toplumsal sınıfların bir yansıması, bir sanat eseriydi. Genel olarak çıplaklık ve belagat bağlamında Antikçağ şehrinin sokakları 
karanlık ve 1şık, kadın ve erkek, köle ve yurttaş ikiliklerinde ve özellikle theatron'da söz sanatıyla şekillenmiştir

\section{"Tanrısal İnsan" ve Kutsal Şehir}

Orta ve Geç Ortaçağ Roma'sında bedenin görülebilirliği Antikçağ Atina'sından farklı olarak mimaride ve sanatta gerçeklik imgesiyle ortaya çıar. Felsefi antropolojinin Yahudi-Hıristiyan Geleneğinde Adem-Havva formunda ön görülen "Tanrısal İnsan" anlayışı başta Roma olmak üzere diğer Avrupa şehirlerinde bir yanda günahından dolayı acı çeken ve Tanrı'nın ışığını arayan münzevi gezgin erkek bedenine bir yandan da Tanrı devletinin yeryüzü temsilcisi olarak şehri ihya eden tüccar erkek bedenine dönüşmüştür. Bu anlayış mekan olarak kapalı kutsal mekanlarda (bazilikalar, kadetraller, kiliseler, manastırlar, evler), limanlarda ve pazarlarda başat imge olmuştur.

Pagan ve ilk dönem Hiristiyan kültürünün bir arada şekillendirdiği Roma, güçlü, kutsal ve tanrısal beden ile zayıf(latılmış), günahkâr ve gölge beden imgelerinin gerilimi arasında birkaç formu bir arada sunmaktadır. Beşinci yüzyılda kiliseler şehirlerin en önemli yapıları haline geldi, Hıristiyanlığın simgeleri ve yapıları şehrin organizasyonunu belirledi, büyük ölçüde de değsşime uğrattı. Şehirler, varlıklarını her zaman gösteren, dogaüstü bir hamilik ve koruma duygusu veren ve dua edilen azizlerin kültleri üzerine kurulan Hıristiyan kimligini kazandılar. (Benevolo, 1995, s. 30-31) Bu dönemde belirgin olarak mimari dokuya ve şehre yansıyan alg1 Hıristiyanlığın ruhanî yapısıyla bedenin simetrisi üzerine kurulmuştur. Vitruvius'un mimariyi insan bedeninin geometrik ilişkilerle, kemikler ile kaslar, gözler ile kulaklar arasındaki simetri üzerine (Vitruvius, 1914, s. 72-73) kurmasından etkilenen ortaçağ mimarları Tanrının yeryüzü temsilcisi, Tanrının yeryüzündeki imajı olan insanın, beden yapısının bir tapınağın mimarisinde nasıl temsil edilebileceğini Roma şehrini ve şehirdeki kutsal mekanları inşa ederek göstermişlerdir. Örneğin, St. Peter Bazilika'sı Kutsal Roma İmparatorluğunun ve Hristiyan hacılarının birleşme mekanı olmuştur. Şehir sosyal, ekonomik ve politik olarak bu bazilika çevresinde kurulmuştur. Ayrıca şehrin korunması için ya doğal surlar (nehirler gibi) ya da büyük sıra sur ve kalelerle şehrin sınırları çizilmiştir (Pounds, 2005, s. 21-22). Beden her türlü şeytanî tuzaklardan ve cadıların büyüsünden korunmak için nasıl kat kat kuşatılıyorsa şehirde düşmanın tuzak ve belalarından korunmak için surlarla çevrilmiştir. Kutsal beden 
imajı ve "kapalı" şehir anlayışıyla Ortaçağ şehri, Antikçă̆ şehirlerinden farklılaşmaktaydı.
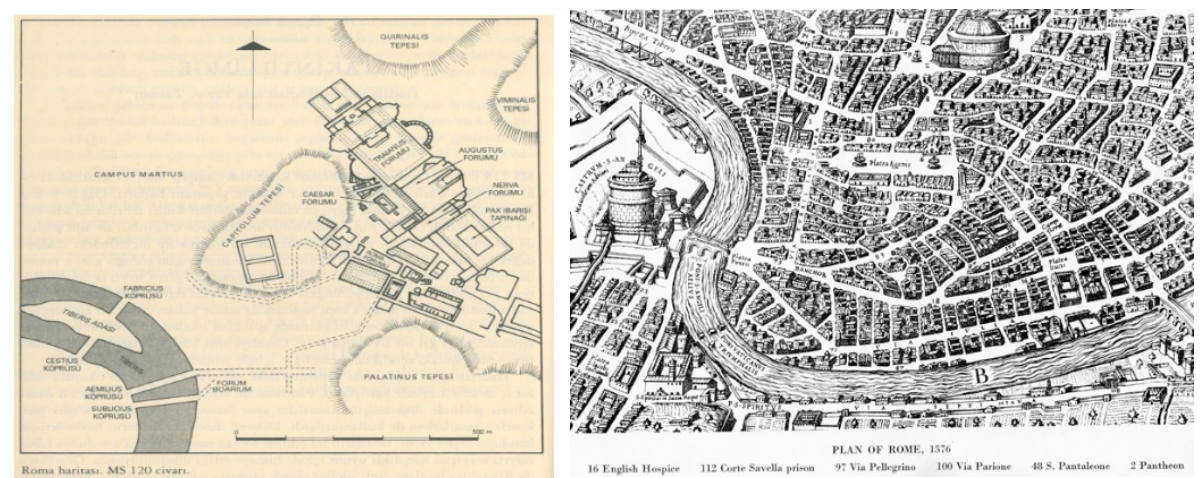

2.yy Roması ve 15.yy Roması

(Kaynak: Sennet, 2002)



15.yy Roma'sı Fransız Gotik sanatıyla çizilmiştir.

Başka birçok Romalı mimarda Roma ve Roma dışındaki şehirleri planlamak için benzer geometrik imgelerden yararlanmışlardır. Şehri kuran bazilikaları çizgisel ve görsel algıya ayrıcalık tanıyan simetri kurallarını kullanarak inşa etmişler (Pounds, 2005, s. 20-23).

Ortaçağda 10.yy'dan sonra seyyahlar aracılığıyla hızla yayılan ticaret, şehrin yapısını ve kilise çevresinde kutsal amaçlarla biraraya gelmenin koşullarını belirlediği gibi piskoposların şehirdeki hakim gücü olarak ticaretin gelişimini ve yeni sınıfların oluşumunu da belirlemiştir. Ortaçağların sonu Renaissance başları olan 15.yy'da ise yeni ekonomik ve toplumsal örgütlenmeler çerçevesinde şehirlerin sayısı giderek artmıştır. Soyluların ve aristokratların yeni üretim ilişkileriyle zenginliklerine 
zenginlik kattıkları bu dönemde ekonomik, kültürel ve sanatsal anlamda tıpkı aristokratların konakları gibi Hıristiyanlığın sembollerini sanatın çeşitli unsurlarıyla birleştirerek şehri inşa etmişlerdir. Bu sembollerle donatılan şehirler birer Hıristiyan özne konuma taşınmışlardır.

\section{"Biyolojik Insan" ve Mekanik Şehir}

Reformla birlikte Katolikliğin günahkâr, kiliseye adanmış ve çileci beden anlayışı yerini özen gösterilmesi, tedavi edilmesi için uğraşılan, Tanrının evi olmasının yanı sıra bir sistem olarak kabul edilen bedene bırakmıştır. $\mathrm{Bu}$ bedenin kutsallığı paranteze alınarak yeniçağ bilimindeki keşifler, icatlar ve kabuller ışığında kalp, kan dolaşımı, iskelet yapısı ve hareketi üzerinden incelenmeye başlanmıştır. Felsefi antropolojinin cins-tür ilişkilerinde doğa bilimleri ve genetik alanında ön görülen "Biyolojik İnsan” anlayışı çerçevesinde beden Renaissance ve Aydınlanma döneminde siyaset, ekonomi ve bilim alanındaki devrimlerle birlikte mekanik pompa, atomik organizmalar bütünü olarak sağlıklı erkek bedenine dönüşmüştür. Bu anlayış mekan olarak düzenli aralıklarla ve benzer fakat atomik formdaki mimarî yapılarla biçimlenen sokak ve meydan planında başat imge olmuştur.

W.Harvey'in 1628 yılında kan dolaşımı keşfi vücut yapısının ve sağlığının ruhla ilişkisinin kavranışında yeni bilimsel bir devrimdir. İnsan bedeninin fizyolojik formu ve işleyişi hakkındaki yeni buluşlar yeniçağ şehirlerinin ve mekanlarının planlamasını doğrudan belirlemiştir. Yeni beden anlayışları bir yandan modern kapitalizmin doğuşuyla örtüşmüş ve bireycilik adını verdiğimiz büyük toplumsal dönüşümün doğmasını sağlamışken bir yandan da modern bireyin yaşayacağı şehirlerin yapısını belirlemiştir.

Renaissance ile birlikte kutsal şehrin unsurlarından yeni ve din dış1 kurumların mimari çeşitliliğinin, cadde ve sokakların planlanmasının da yeni bilimin kabullerini yansıtan ilişkilerin belirleyici olduğu şehir anlayışına geçildiği görüyoruz. Bu anlayışın ilk somut örneği "Veni etiam" tekrar tekrar gidilen yer anlamını taşıyan şehir Venedik'tir.

16.yy'ın başlarında yaşanan savaşlar ve kara ölüm olarak bilinen veba İtalya ve özellikle Venedik'i kuşatmıştır. Bu yaşanan savaş ve salgın tehdidinin ardından şehir politik ve fiziksel olarak yeniden planlanmıştır. Venedik coğrafî imkanlarla birlikte insanın hem kendi içine hem de şehre yolcuğunu temsil eden bir planla yeni baştan kurulmuştur. 




17.yy Venedik, (Kaynak: Sennet, 2002)

Venedik'le başlayan yeni şehir ve yeni şehirli algısı Harvey'in keşfiyle birlikte hız kazanan bilimsel çalışmalar Avrupa şehirlerindeki günlük yaşamı ve şehirlerin fizikî planlarını etkilemiştir. Bu etkiler ve değişim özellikle Karlsruhe ve Paris şehir planlarında açıkça gözlemlenebilmektedir.



18. yy Karlsruhe, Dolaşıma dayalı ilk şehir planı, (Kaynak: Sennet, 2002)

“Harvey'in devrimi insanların şehir ortamından beklentilerinin ve onun için yaptıkları planların değişmesine neden olmuştur. Harvey'in kan dolaşımı ve solunum hakkındaki bulguları kamu sağlığı hakkında yeni fikirlerin doğmasına yol açmıştır. 18.yy. Aydınlanmacı şehir plancıları bu fikirleri şehre uygulayarak, şehri insanların serbestçe dolaşıp nefes alabilecekleri bir yer, insanların sağlıklı kan hücreleri gibi içinde aktığı akışkan atardamar ve toplardamarlardan oluşan bir mekan haline 
getirmeye çalışıyorlardı." (Sennett, Ten ve Taş, 2002, s. 230) Başka bir ifadeyle, modern dönemde beden mekanik, biyolojik formda salt bir dolaşım ve boşaltım sistemi olarak fiziksel yasalara bağlanmış, kutsallıktan ve cinsiyetten kısmen arındırılarak kanın pompalandığı, cildin sağlıklı ve parlak (temiz) olduğu, her türlü aksaklıktan ve "çirkinlikten" arındırılmış bir mekan olarak kabul edilmiştir. Modern dönemde bedene ilişkin bu yargıların altında yatan bir diğer neden ise teknolojinin ve ticaretin ürünlerinin açılama modeli olarak kullanılmasıdır. Örneğin, 17.yy'da bu model mekanik saatlerdi; 18.-19.yy'larda buhar makinesiydi ve 20.yy'da ise bilgisayarlardır (Danto, 2014, s. 94). Bu beden imajlarından oluşan şehirler kanalizasyon sistemlerinin (boşaltım sistemi olarak, saatin çarkları, buhar makinesinin işleyişi) ve bireylerin serbetçe hareket edebilmesi için ulaşım akslarının, sokak ve caddelerin simetrik olarak inşa edildiği (dolaşım sistemi olarak) mekanlara dönüşmüştür. Mesela, ızgara planı çerçevesinde aynı yöne giden ana caddelerin sayısı arttırılmış ve daha uzun yapılmış, perspektif yasalarının hakim olduğu planlar ve mimarî dokular ön plana ç1kartılmıştır.

Coğrafî keşifler ve yeni haritacılık bilgileriyle mekanın ve sanayi devrimi ve kol saatiyle zamanın hakimiyet altına alınması, yeni ekonomi ve yeni toplumsal sınıfların ortaya çıkışı göstermiştir ki, modern insan göçer olmanın dışında mekanla kayıtlı hareket eden bir bireydir. Dolayısıyla bu bireyin inşa ettiği şehir de hareket merkezinde planlanmıştır. Tıpkı vücutta kanın dolaşması gibi bireyin şehirde serbestçe, engelsiz ve hızlı hareket etmesini sağlayan gösterge sistemleri kurulmuştur. Bunun yanı sıra birey ve şehir (mekan) arasında duyusal farkındalığın yönlendirilmesi, şehrin farklı yerlerinde ve bu yerlerdeki insanların yarattığı uyarımların azaltılması ve mekanların nötrleştirilmesi de beraberinde gelmiştir (Sennett, Ten ve Taş, 2002, s. 229).

Bu dönemde Avrupa şehirlerinin yapısını belirleyen faaliyetlerin başında yaşayan bir organizma olarak şehrin fonksiyonlarının mükemmel duruma getirilmesi yer alıyordu. (Benevolo, 1995, s. 104) Bu amaçla tıpkı Harvey'in insan anatomisini yeniden tanımlaması gibi şehrinde belli başlı merkezi yapılarının tamamlanıp bu yapıların restoransyonu ve kamu alanlarının örgütlenmesi gerçekleştirilmiş, yeni kamu yapıları ve özel yapılar tanımlanmıştır. Çünkü ‘Aydınlanma plancıları şehrin sağlıklı bir beden gibi işlemesini, tıpkı temiz bir cilde sahip olmasının yanı sıra serbestçe akacak bir şekilde tasarlanmasını istiyorlardı.' Bu anlayışın somutlaştığı örnek 18. yy. Paris'nin St. Louis Meydanı'dır (Sennett, Ten ve Taş, 2002, s. 237). 




18.yy. Paris St. Louis Meydanı (Sennett, 2002:241)

Şehirlerin fiziksel olarak düzenlenmesi yapılandırılmasının yanı sıra toplumsallaşma ve yeni ekonomik ilişkiler bağlamında Harvey'in keşiflerini Adam Smith oldukça farklı bir boyuta taşımıştır (Sennett, Ten ve Taş, 2002, s. 229). A. Smith Ulusların Zenginliği adlı eserinde serbest emek ve mal piyasasının beden içinde serbestçe dolaşan kana çok benzer biçimde işlediğini ve şehirler için (tıpkı bedende olduğu gibi) hayat verici sonuçlar doğurduğunu iddia etmiştir. Bu insan ve şehir anlayışı felsefi antropoloji içindeki değişimin önemli bir aşaması olan yeni insan -özne/ şehir-özne tanımına yol açmıştır.

\section{"Aydınlanmanın 'Özne' Tasarımının Çöküşü" ve Modern ve Postmodern Şehirler}

"Aydınlanmanın 'Özne' Tasarımının Çöküşü” anlayışında ancient régime imajları tıp alanındaki yeni gelişmeler, teknolojinin yeni ürünleri, el emeğine dayalı işin gerilemesi, ekolojik krizler ve yeni kapitalist idealler bağlamında yıkılan "Aydınlanmanın 'özne' Tasarımı" hem bilinç hem de anlam düzeyinde dağılan ve değersizleşen hibrid cinsiyetli "yalnız birey" bedenine dönüşmüştür. Bu anlayış mekan olarak görsel imaj odaklı sahne ve vitrin ilişkisinde yekpare, tarihi ve geleneksel olandan soyutlanmış mimarî yapılarda, ilişkisiz - bağlamsız "yerlerde" başat imge olmuştur.

Bedenin mekanla kurduğu ilişki açısından mekan bedensel hareketin aracı haline gelmiştir. Mekanları, insanın bedenine uygun olarak tutarlı ve bütün hale getirilen şehirler, özellikle 19.yy'dan sonra nüfus yoğunluğuyla birlikte ekonomik ve politik ilişkiler açısından sadece seküler bir iktidarın yeri ve "gündelik" hayatın çıkarlarına hizmet eden mekanlar olarak alg1lanmaya başlanmıştır. Bu dönemde şehirler büyük oranda herhangi bir etik 
ve estetik referansı olmayan, duyumsuz mekanik hareketin mekanına dönüştürülmüştür. Modern şehirler artık aydınlanmanın hümanitasını temsil etmemektedir, insan için yabancılaşan ve insan varoluşunun dinamik mekanı olmaktan uzaklaşan formdadır. Şöyle ki, 'şehirlerdeki mekan salt hareketin bir işlevi haline geldikçe kendi içindeki uyarım kapasitesini de yitirir; birey sürücü olarak mekanın içinden geçip gitmeyi ister, onun tarafından uyarılmayı değil' diyen Sennett'i haklı çıkaran etik değerden yoksun ve yapısı açısından değil işlevselliği ve ekonomik oluşu açısından estetik değere sahip şehir formları gelişmiştir.



Barcelona Şehir Planı

Kaynak: http://blog.kavrakoglu.com/tag/modern-ve-postmodern-sehir-planla$\underline{\text { masi/ }}$

Modern şehrin mekanları kısmen festival havasında yaşanan haz ve acının kısmen de gerçek iletişimin ve ilişkilerin zayıfladığı (kimi zaman sanatçılar için "verimli yalnızlığın" yaşandığı kimi zaman da ontolojik boşluğun hissedildiği) bir mekana dönüşmüştür. Lefebvre'in kapitalist toplumda şehir mekanının sermaye, devlet ve halk tarafından nasıl görülüp deneyimlendiğini açıklamak üzere geliştirdiği üçlü şeması dönemin şehir imajını anlamamızı kolaylaştırmaktadır. Şemadaki öğeler mekan üretimine üretim tarzı ve tarihsel döneme bağlı olarak farklı kombinasyonlarla katılırlar: Algılanan Mekan (Mekânsal Pratik) mekansal pratik 
tutarlılığı performans ve yeteneğin sağlanmasıyla amaçlamaktadır. Neokapitalizm altındaki mekansal pratik içinde günlük gerçeklik (günlük rutin) ile şehrin gerçekliği (rutinleri, mekanları bağlayan ağları) ilişkilendirir. Tasarlanan Mekan (Mekanın Temsili) üretim ilişkilerine ve bilgi, işaret, kod ve açıklık arasındaki ilişkilerin düzenine bağlıdır. Bilim adamlarını, plancıların, şehircilerin, sosyal mühendislerin vs. kavramsallaştırdıkları mekandır. Mekan kavramları verbal (sözsel) işaretler sistemi şeklindedir. Yaşanan Mekan (Temsilin Mekanı) kendi nesnelerini sembolleştirerek fiziksel mekanı kaplar. Burada sözsel olmayan fiilî, görsel semboller söz konusudur. Kullanıcıların ve oturanların doğrudan içinde yaşadıkları mekandır ve tutarlılık aramak zorunluluğu yoktur. (Lefebvre, 1991, s. 37-38) Bu mekanlar modern özneler tarafından şehrin çelişik ve fakat diyalektik bir süreçte nasıl duyumsandığının da göstergesi olmuştur. Şöyle söyleyebiliriz, modern şehirlerin ve modern bedenlerin bu kaotik yapısı bir 'çöküşün, dağılışın' ifadesi olarak gerçekliği tam bir temsile dönüştürmüştür.

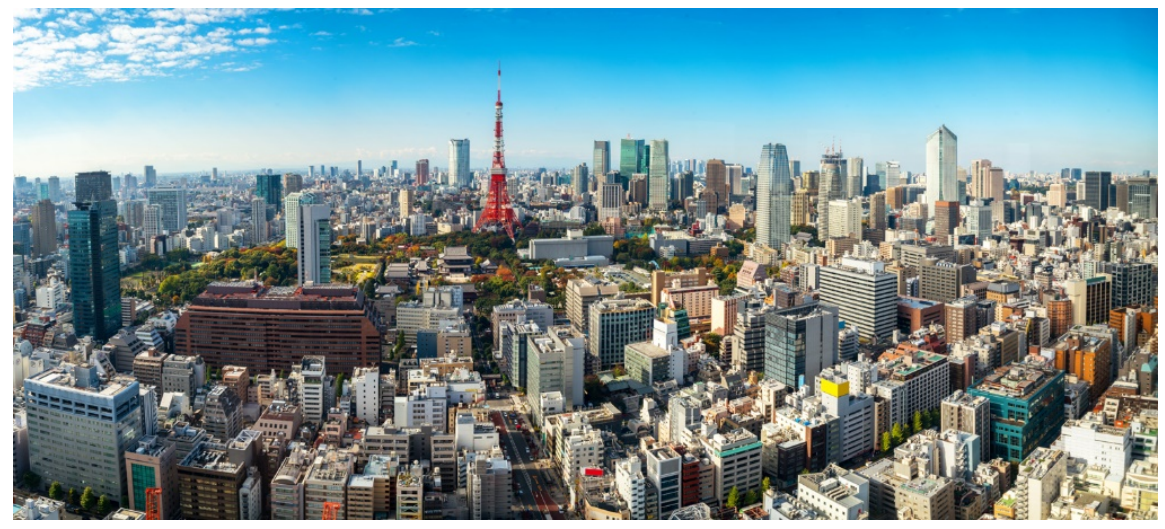

Tokyo Kulesi

Kaynak: https://www.wfanet.org/events/2017/10/save-the-date-global-marketer-week-2018/

Yeni şehirlerde ortaçağların sonlarından ve yeniçağla birlikte değişen ticaretin, kültürün ve politikanın ürünü olan şehirli nüfusun artışıla toplumsal yapıda önemli değişiklikler meydana gelmiştir. Değişiklik birçok yerde kol emekçiliğinin aşılarak teknoloji ve sanayileşme aracılığıyla makineleşmenin yaygınlaşmasının yanı sıra farklı toplumsal sınıfların (rahipler, tüccarlar, aristokratlar, burjuvalar, sanatçllar, vb.) ortaya çıkmasına da neden olmuştur. 
Özellikle küreselleşme ve kapitalizmle birlikte yeni ve farklı sınıfların ortaya çıkışı toplumda çok daha uzmanlık gerektiren işbölümü anlayışını da beraberinde getirmiştir. Böylece modern şehirler hem bu değişimin getirdiği yeni piyasa anlayışına hem de insan bedenine dair yeni bilimsel buluşlara bağlı olarak şekillendirilmekte ve kutsal mekanlar, yönetim binaları, kamu binaları ve özel tasarlanmış meydanlar şehrin simgesi olarak ön plana çıkarılmaktadır. Başka bir ifadeyle, modern şehir insan ve mekanı birbirine indirgeyen bir bütünsellik çerçevesinde sınıflandırılmış/sınırlandırılmış mekanik saat gibi kapalı devre tasarımlanmıştır. Felsefi antropoloji tartışmalarındaki değişen özne anlayışı göz önüne alındığında 19.-20.yy'larda şehirlerinin ekonomik büyüme ve küreselleşme senaryoları çerçevesinde tek biçimlileştirildiğini ve kartezyen özne eleştirileriyle şekillenen anti-özneyi (özneleri) ve çeşitliliği temsil etmedikleri, evrensel bir form (iktidar) üzerinden tasarlandıkları görülmektedir. Aslında bu büyük bir yanılsamanın göstergesidir ayn zamanda. Çünkü bir taraftan yerellik, çok kültürlülük, çoğunluk, çeşitlilik yaşam pratiği olarak sunulurken bir taraftan da bunların evrensel ilkelere dönüştürülmesi bu yanılsamanın göstergesidir. Modern şehir planlarının yanı sıra bir yandan da anti-özne ve flanuer anlayışını temsil eden postmodern şehir planları bu yüzyılda eş zamanlı olarak vardır. Postmodern şehirler aynı zamanda üçüncü dünya ülkelerini diyazn etmenin ilkesi olarak işlerlik kazanmıştır. Modern şehre hakim olan rasyonel, kapsamlı plan anlayışıyla postmodern şehrin proje odaklı plan anlayışı çağdaş insanın kaotik yapısının mücessem haline olarak karşımızda durmaktadır.

Postmodern şehir, bölünmüş, arkeolojik ve antropolojik formların ard arda geldiği kolajlardan oluşan, değişken, geçici ve dinamik olarak algılanmaktadır. Şehir proje alıcılarının zevkine, ihtiyaçlarına ve yönelimlerine göre planlanan projelerin dağılımıyla form kazanmaktadır. Böylece diyebiliriz ki, postmodern şehirler anti-öznenin değişkenliği, indirgenemezliği ve çeşitliliği doğrultusunda bütünsel bir tasarımın konusu olamayacağı iddiasının göstergeleridir. 20.yy'da antikçağ ve ortaçağa göre şehirler fiziksel bir büyüklüğe erişmişlerdir ve artık merkezden çevreye klasik anlamda yapısal insan anatomisine göre değil, toplumsal sinıflara göre ve daha atomik formda planlanarak yeniden yapılandırılmıştır. 20.yy'ın başında modernitenin ütopik perspektifiyle form kazanan, "gelişen" ve yepyeni bir yapıyla planlanan birçok şehir postmodernitenin argümanlarıyla eleştirilmiştir. Ebenezer Howard, Le Corbusier ve Lloyd Wright gibi 20.yy'ın en etkili postmodern şehir plancları şehir hayatı için yepyeni bir form, bir ütopya geliştirmişlerdir. Onlar için 20.yy ideal şehrinin nasıl olacağını planlamak insanın ve şehirlerin 
yaşadıkları varoluşsal problemleri de çözmek anlamına geliyordu. Bu çerçevede onların ütopyalarına gerçeklik alanı bulmak ve uygulamak mimar ve mühendislerin çabalarıla mümkün olmuştur. Postmodern mimarlar ise planlamayı değil, tasarımı merkeze almışlardır. Postmodern mekan tasarımları toplumsal amaçları değil mimarın ve proje alıcısının beğeni, beklenti ve taleplerini yansitır olmuştur. 20. yy'da insanlar gibi şehirlerde yaşayan birer canlı habitus olarak kabul edilmiş fakat yeni bir "yaşam alanı" konsepti getiren bu plancılarla şehirler daha parçalı yapıya ve şehirlerde kurulan ilişkiler sınıfsal birlikteliğe dayalı olarak sokak, cadde ve meydanlar tüketim ve trafik değişkenlerine göre şekillendirilmiştir. Mesela, grafikte soldaki resimde (ortak özekli bölgeler kuramında) görüldüğü gibi şehir, merkezden çevreye doğru ekonomik ilişkiler ışığında sınıflandırılmıştır. Bu grafiğin son halkasından itibaren (sitelerin ve üst gelirlilerin yaşam alanı,) ki şehrin temel sınıflandırması içinde yer almamaktadır, gettoların başladığı bir şehir planı kurulmuştur. Postmodern şehir modern şehrin karşısında, ondan farklı ilke ve kabuller çerçevesinde inşa edilmiştir. Onu farklı özne-birey anlayışındaki değişim ve ekonomik evrilme noktalarıdır. 20.yy'da biyolojik, toplumsal ve siyasal sınırlarını kaybeden birey gibi şehirlerin sınırları da değişime uğramıştır. Bireyin zaman ve mekan algısı, doğa tasavvuru ve çevreyle ilişkisi araçsal bir form kazanmıştır. Postmodern şehirde kullanılan malzeme ve geliştirilen yeni teknolojilerle, tasarımlarla, yeni siyasî ve ticarî ilişkilerle neresi iç mekan neresi dış mekan, sınırlar nerede başlıyor nerede bitiyor belirsizleşmiştir (Kleniewski, 2005, s. 57).

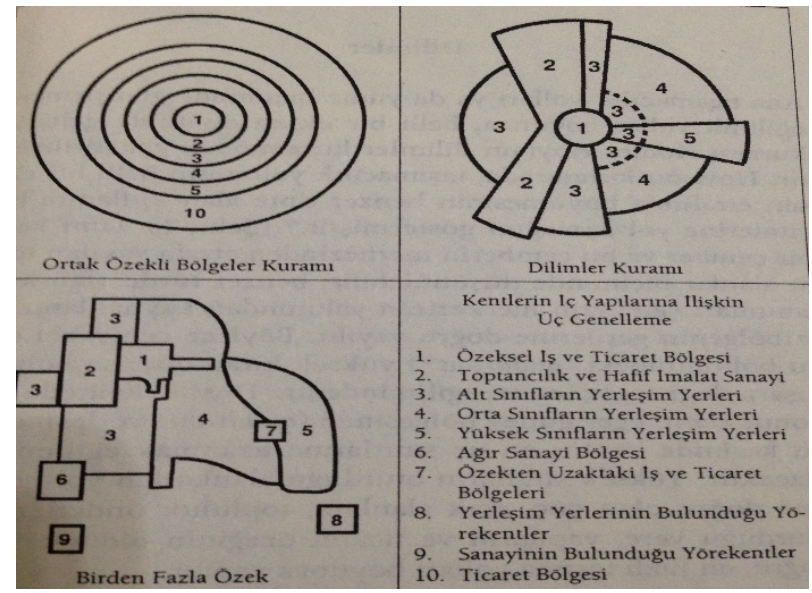

Harris ve Ullman

Kaynak: (Ullman \& Harris, 2002, s. 67). 
Özgürlük bağlamında postmodern şehirler, kendi hikayelerine odaklanmış bireylerin, "ötekilerin" hikayelerinin iğreti olarak dinlediği-izlediği, "başka" hikayelerin duyulduğu ve özellikle hem bilmek hem de eylemek ediminden yoksun sadece "seyirci olarak" dahil olunduğu etkileşimsiz bir tiyatro sahnesine dönüşmüştür. Bireyi silen ve yabancılaştıran bu yap1lanma sahne, sokak ve vitrin üçgeninde, sokakla ilişki kurmadan bir yerden bir başka yere akan maskeli kimlikleri "yersizleştirerek" özgürlükleri ve özgünlükleri arasına mesafe koymaktadır. Ortaçağlarda ve Renaisance'ta sokağın başlangıcı ve sonu olan 'bilindik-bildik' formu, sahiciliği ve "res publica" oluşu sahneyle, sahnenin "kostümü" günlük giyisilerle, sahnenin dekoru gerçek yaşam alanıyla ve oyunun aktörü sokağın günlük bireyiyle özdeşleşerek bir dönüşüm yaşamıştır. Sahnede de gerçek kamusal ve mahrem açısından birbirine karışmıştır. Bedeniyle aktif ve sahici tecrübeleri olan sokağın bireyleri sahnenin karşısında bir izleyiciye dönüşmüştür. Böylece etik, estetik, hukuk ve bilim çerçevesinde her türlü eylemin mekanı olarak beden şehir ve sahneyi birbirine bağlamıştır ve fakat insanı özgünlügünden-kendilik bilincinden uzaklaştırmıştır. Postmodern şehirler, insan bedenlerinin çeşitliliğine saygı göstermek bir yana, ekonomik ve politik üretimlerle tek tipleştirme, tüketme ve hatta kimlikleri ayrıştırarak yok etme üzerine kurgulanmıştır. Bu yüzyılda şehre form kazandıran insan değil, insana form kazandıran şehir olmuştur ve şehrin iktidar vurgusu belirgin biçimlendirici "güç" olarak kendini ortaya koymuştur.

Şehirli bireyi saran "can sıkıntısı" ve "bunaltı" bedensel duyumu ve fiziksel özgürlükleri giderek azaltmıştır. Başka bir ifadeyle, postmodern şehirler, trafiğin akışına göre planlanan ve hızlı seyahat etmenin dolayısıyla hareketin aracı olduklarından, postmodern bedenler için bütün duyusal uyarıcılarından sıyrılarak daha hızlı ve kolayca hareketin mümkün kılındığı nötr ve homojen bir form kazanmışlardır. Bu dönemde insanın mutluluğu etik ve estetik değerler bağlamından günlük yaşamın ihtiyaçlarını kolayca karşılayabilme özgürlüğüne, mekanik olarak sağlıklı olmakla eşleştirilmiş ve sağlıklı olmak da bireysel olarak şehir içinde serbest, rahat ve hızlı "özgür" hareket etmekle örtüştürülmüştür. Böylece bu sistemde mutlu ve sağlıklı birey şehir içinde ait olduğu "tek bir yer" olmadan farklı mekan ve zaman tecrübesini edindiği bir şehirin öznesidir. Bu durum Hegel'in eleştirilerinin somutlaştığı yuvasızlık- "yersizlik" anlayışında ve Heidegger'in de "şimdi ve burada" olma anlayışında (farklı bağlamda da olsa) temelini bulur ve postmodern birey-mekan ilişkisi de bu "bağlamsızlıkta" açıklık kazanır. Bu düzende mekanda hızlanan, artan 
ve yoğunlaşan ilişkiler Harvey'in postmodern durumda tanımladığ gibi bilgi ve iletişim teknolojileri aracılığıyla zaman -mekan sıkışmasını hızlandırmıştır.

\section{Şehir ve Beden İlişkisinin Bağlamı: Özgürlük ve Kaos}

Şehir ve beden ilişkisi tarihi süreç içinde birçok farklı veçhesiyle ortaya çıkmıştır ve iktidar imajın belirleyiciliğinde insanın şehir içindeki hareketliliğini ve özgürlüğünü birçok boyutta kısıtlamıştır. Mesela, sözün hakim olduğu, konuşma-dinleme merkezli meydan anlayışını temsil eden Atina yurttaşı iktidar sesin kölesi olurken kutsal ya da seküler her türlü görsel imajın hakim olduğu ortaçağ Roma'sının ve yeniçağ Avrupa şehirlerinin yurttaşı da gözün kölesi olmuştur. Modern ve postmodern dönemde ise söz ve görsel imajlar teknolojinin yaptırımıyla sanal bir mekanda polifonik sese ve çoklu görsel imaja dönüştürülerek yeni tür köleliğin temeli oluşturulmuştur.

Özgürlük alanlarının açılması ve her bireyin kendini ifade edebilmesi "öteki" adlandırmasıyla dışarda bırakma anlayışını aşabilmesi ortak faaliyet mekanlarının inşa edilmesiyle mümkündür. Weber'in ortaçağ şehirlerini tanımlarken kullandığı 'şehir havası insanı özgür kılar' mottosu Avrupa şehirlerinin ve kurumsal yapılanmasının da mottosu haline gelmiştir. Gerçekten de şehirlerin tarih boyunca gelişim süreci göstermiştir ki, özgürlügün özellikle politik özgürlüğün en yoğun yaşandığı mekanlardır şehirler. Braduel'e göre şehirler, elektrik transformatörlerine benzerler, gerilimi yükseltir, değişimin ritmini hızlandırırlar ve insan hayatını sürekli yeniden doldururlar. Fakat, bununla birlikte, 20. yy şehirlerinde nüfus artışı ve ekonomik çeşitlenmelerle dolaşımı hızlandıran mekan planları iktidarın yapısını görünmez kılan ve "meydanı kontrol eden şehri kontrol eder" yargısını destekleyen mimarî yapılarıyla iktidarı izleyen ve manipüle eden bir perdeli güce dönüştürmüştür. Başka bir ifadeyle, siyasî erk çoğu zaman şehir altyapısını ve şehir yaşantısını farklı kitlesel hareketleri denetleyecek şekilde planlamaktadırlar. (David, 2013, s. 173) Bu bir araya gelmeyi engelleyen politik merkezli yapılanma, kitlesel hareketi engelleyen parçalı meydanlarla, kitlesel hareketin arzu ve duyumlarını yönlendiren ve bilinçli eylemlerini kıran AVM'lerle, parklarla ve müzelerle özgürlük konusunda farklı bağlamlarda birçok tartışmaya kapı aralamıştır. Özellikle, 19.yy'ın başına kadar açı olan ve park formunda tasarlanan meydanlar, cam çatılar ve cam duvarlarla kapatılarak, kendi içinde özgür 
ama dışarıya kapalı (tıpkı modern birey gibi) yeni tür meydan algısıyla tasarlanmaya başlanmıştır (Bloomer\&Moore, 1977, s. 82-85). Kamusal mekanın üretiminin, bu mekana ve kamusal hizmetlere erişimin hangi yoldan, kim tarafından ve kimin çıarları doğrultusunda denetleneceğine dair bir mücadele her zaman süregitmiştir (David, 2013, s. 125).

Birey olarak insan, inşa ettiği bu mekanlarda hem kendi fiziksel sınırlarını hem de toplumsallaşma sürecini biçimlendirmektedir. "Farklılıklar biraraya gelerek toplumu ve şehrileri oluşturur" anlayışından hareketle birçok farklı bireyin biraraya geldiği ve özgürce yaşayabilecekleri, dönüştürebilecekleri ve birlikte var olabilecekleri mekanların inşa edilebilmesi ve böylece bir şehrin meydana getirilmesi için temel alınan insan anlayışı ve insan faaliyetleri önem kazanmaktadır.

Farklılıklar etkin olmaktadır, fakat bu mekanlarda özgürlük her zaman tartışma konusu olmuştur. Aktör olarak insanın kendi elleriyle inşa ettiği mekanlarda 'özgürlük' ve 'iktidar' ilişkisi çoğu zaman çatışma alanları oluşturmuş ve eylem alanı olarak şehirle beden özdeşleştirilmiştir. Şehir ve beden arasındaki bu ilişkide şehir, Foucault'a göre disiplin edici güç ve iktidar unsurlarının en başta gelen etkinlik alanıdır; Lefebvre'e göre kapitalizmin soyut mekanı içinde araçsallaştırılan bedene direnmek üzere, duyularla ilişkili ve anlam arayışında "yaşanan mekan"ın üretimi için bir potansiyeldir. Merlau-Ponty'e göre toplumsallı̆ın ve soyut kavrayışlardan önce vücut bulan eylemlerin alanıdır (Berber, 2011). Baudrillard'a göre çağımızda beden yeniden keşfedilmiştir, fakat bu keşif sonucunda beden tüketim amaçlı bir metaya dönüştürülmüştür. Özellikle kadın bedeni, kitle kültüründe, moda ve reklam dünyasında kuşatılmış ve nesneleşmiştir.

Bu bağlamda modern-postmodern şehir, üretim ve tüketim süreçlerine göre inşa edilen büyük bir sahne ve vitrin (AVM- modern pazar) olarak farklı iktidar yapıları tarafından planlanmıştır. Kapalı mekanlarla insanı kuşatan ve kalabalıklar içerisinde sürüklenen sıradan bir canlıya dönüştüren bu yeni şehirler gelecek araştırmalar için iki problem alanına yol açmışlardır. Bunlardan ilki, kapitalizmle şekillenen ve cinsiyet çatışmasıyla yüzleşen hümanizmin 500 yıllık insan anlayışını yeniden yorumlamaya zorlamaktadır. İkincisi ise, 20.yy'da şehirleşmeyle birlikte ortaya ç1kan yeni ekoloji (antropocene) tartışmaları çerçevesinde posthümanizmin, transhümanizmin viral bedenlerin-cyborgların şehir mekanına yansımasını dolaşıma sokmaktadır. 


\section{Sonuç}

İnsanlığın bütün başarıları ve kayıpları binaları ve kültürüyle ona somutluk kazandıran şehrin fizikî ve sosyal yapısında içerilir. Şehirlerin ve insanlığın tarihi dikkate alındığında, insan anatomisinin bir yandan fiziksel mekanın biçimlendirilmesinde ve mekandaki faaliyetlerin belirlenmesinde bir yandan da mekanın sosyal yapılandırılmasında ve simgeleştirilmesinde referans olarak kullanıldığı görülmüştür.

İnsan doğasının neliği ve insanın anlam arayışı bağlamında Antikçağda ticarî ilişkilerin merkezi olan şehirler, doğayla özdeş sayılan bedenden ve bedenin isısından hareketle planlanıyordu. İmaj ve planlama etkinliği açısından tarihsel süreç içinde antikçağ Atina'sında şehre formunu veren ve şehrin siyasî mekanlarını dönüştüren "beden" genç Atinalı erkek bedenidir. Hristiyan ortaçağıyla birlikte "doğadan kopan", "doğaya yabancı" olan, "doğaya fırlatılan" "günahkâr" beden anlayışılla gittikçe bireysel, mekanik ve hatta kaotik bir form kazanan bedenin simetrisinden ve Tanrıya göre konumundan hareketle planlanmaya başlanmıştır. Ortaçă̆ Roma'sında şehrin tapınak ve katedrallerle renkliliği ve çeşitliliğini temsil eden "beden" paganların ve arınmışlığın sembolü olan genç hıristiyan erkeklerin bedeni olmuştur. Rönesans ve yeniçağda keşiflerle, bilimsel buluşlarla ve teknolojinin üretimiyle beden, hakikatin temsilcisi olarak kabul edilmiştir. 'Kendini bilmek' kendine özen göstermek ve sağlıklı, güçlü ve bakımlı bir bedene sahip olmakla özdeşleştirilmiştir. Böylece beden sadece şehrin mekanlarında akan ve estetik bir form kazandırılması gereken pasif bir mekana dönüşmüştür. Rönesans Venedik'inde şehirde değeri ve iktidarı temsil eden "beden" yurttaş hıristiyan erkek bedeniyken, yeniçağ Paris'inde şehrin devrimin ve demokrasinin temsili eşitlikleri besleyeceğine bir ideal olarak inanılan cinsellikten uzak bir kadın bedeni olmuştur. 19.yy'la gelinceye kadar insan bu dünyadaki bedeni için değil, öte dünyadaki ruhuna ulaşmak amacıyla yaşamıştır. Bu yy'dan sonra ise öte arayışları ve cennete dönüş umudu kalmayan insan, kendi cennet bahçesini şehirler inşa ederek kurmayı amaçlamıştır. Bu insan için beden, ruhun hapishanesi olmasının dişında hayatın anlamını temsil eden ve yolculuğunda onu acılardan hazlara taşıyacak birincil bir araç olarak kabul edilmiştir. 20.yy'dan itibaren Platon'un 'kendini bil' (gnothi sauton) çağrısını destekleyen 'kendine özen göster'(epimelesthai sauton) çağrısı yalnızca beden olarak kendine özen göstermeye dönüştürülmüştür. Başka bir ifadeyle, özellikle 20.yy'da kitle iletişim araçlarının beden üzerindeki 
baskısı, diyet formülleri, estetik operasyonları, egzersizleri, kusursuz beden imajları şehirli insanı etkisi altına alarak varoluşsal çöküş yaşayan insan anlayışına zemin hazırlamıştır. Bu noktada Baudrillard'ın "insanı cezalandıran artık Tanrı değil, bedeninin tam da kendisidir" yargısı sorunu apaçık ortaya koymuştur. Çünkü insan artık plastize olmuş bedeninin tahakkümü altındadır, onu yok sayarak ya da ondan uzaklaşarak değil bilakis onu (Sartre'ın dediği gibi bedenim ben'im) 'ben'in kendisine dönüştürerek' kutsamıştır. Bu beden anlayışının yansıdığı şehirler artık bir değer, kimlik ve özgünlük taşımaktan uzak, pazar imajına göre inşa edilen ve birbirini tekrar eden yüzlerce mekana dönüştür.

Şehirlerin ve şehirle bağlantısı çerçevesinde bedenin tarihi göstermektedir ki yüzyılımızda şehirler, hayatın bütün akışı içinde 'anlamlı' bir faaliyet alanı olarak insanın kendisini gerçekleştirdiği ve aynı zamanda da kendisini birey, kişi ve ben kapsamında bedene indirgeyerek 'homo saphiens', 'homo faber', 'homo ludens' ve sonuçta da 'siberantropos' adlandırmasıyla var kılarken tükettiği ve yok ettiği antropolojik distopya mekanlarına dönüşmüştür. Zaman algısı da bu dönüşümden payını almıştır. Zaman artık şehirdeki hareketlilik ve bedenin bu hareketliliğe uyumu üzerinden okunan bir şimdi olmanın ötesindedir. 20.yy'ın başlarına kadar şehirdeki faaliyetlerinin düzenlenişinin bir aracı olan zaman kaotik bir parçalanmışlığın imgesi olmuştur. 


\title{
Extended Abstract
}

\section{Two Sides of Relationality: Body and City}

\author{
Yaylagül Ceran Karataş \\ Medeniyet University
}

In the history of the western modern era, which faced with drastic changes in science, economy, politics, and art perspectives, ontological and an aesthetical correlation between city and body turn into a mechanic and meaningless structure. This changing is clearly seen "new city designs" of architects and city planners. Conflicted between sacred, tradition and modernity creates strange meaning about body and city relations as Sennett said: "there is a strange destiny when body language has been translated city space". This destiny signified that perceiving body is how the city is perceived. In this article, Two Sides of Relationality: Body and City, we discuss how body images translate into city plans while inquiring the Ancient Athen, the Middle Age Roma, the Renaissance Venice, the New Age Paris, and Modern-Postmodern cities in the context of 20th century. As a source of images and memories, it symbolizes "who belongs" in specific places. As a set of architectural themes, it plays a leading role in city planning strategies based on historic preservation or local "heritage." Our argument is "cities have an onto-anthropologic dynamic space rather than mechanic-static spaces". We bring this idea up for discussion via philosophical anthropology and city planning theories in terms of understanding of body imaginations which underlies background of global cities.

All the achievements and losses of humanity are included in the physical and social / moral structure of the city, which gives it concreteness with its buildings and culture. In this term, city planners and philosophers collaborate on the planning of the cities. In this process planning cities has two main sides. First one is physical structure of the city and human being and the second is moral and historical orders of human behaviors and cities. In other words, cities are rooted in the habits and customs of the people who 
inhabit it. Considering the history of cities and humanity, it has been seen that the human anatomy is used as a reference in shaping the physical space and determining the activities in the space but also in the social construction and symbolization of the space.

In the context of human nature and the search for the meaning of human, cities, the centers of commercial relations in ancient times, were planned with reference to the body considered to be identical to nature and the temperature of the body. In the historical process from the point of view of image and planning activity, "body" is the young Athenian male body that forms the city in ancient Athens and transforms the political spaces of the city. With the Christian Middle Ages, the city began to be planned by the symmetry of the body, which gained an individual, mechanical and even chaotic form, and the location of the body according to God. At the same time, the city was planned with the body understanding of "detached from nature", "strange to nature", "flung", "sinner". The "body", which represents the color and diversity of the city with temples and cathedrals in Medieval Rome, had been the body of young Christian men who were symbol of pagans and purity. The body was accepted as the representative of the truth with the explorations, the scientific discoveries and the production of technology in the Renaissance and the New Era. "Self-knowing" is associated with self-care and having a healthy, strong and well-groomed body. Thus, the body was transformed into a passive space, which only walked in the spaces of the city and needed to be given an aesthetic form. While "the body" representing the value and the power in the city in Renaissance Venice was the citizen Christian male body, the city in the modern age Paris became a female body far from sexuality and that female body was believed to be the ideal of the city, revolution and democracy. Until the 19th century, human lived in order to reach the spirit of the hereafter rather than her/his body in this world. After this century, human who has no hope of returning to heaven and seeking for the hereafter aimed to build her/his own paradise garden by building cities. For that human, the body was regarded as the primary means to represent the meaning of life and to carry her/him from grief to pleasure on her/his journey in addition to being a prisoner of the soul. From the 20th century, Plato's invitation "self-care" (epimelesthai sauton) which supported his invitation "Know thyself" (gnothi sauton) has been transformed into only a self-care as a body. In other words, especially in the 20th century, the pressure of the mass media on the body, diet formulas, aesthetic operations, exercises, perfect body images has provided a basis 
of the understanding of human who experiences existential collapse. At this point, Baudrillard's judgement "God is not who punishes the human anymore, but her/his body" clearly reveals the problem. Because human is now under the domination of plasticized body. Human blesses that body not by ignoring it or not by moving away from it, but (as Sartre said "I am my body".) by transforming it into herself/himself.

The cities in which this concept of body reflects are now transformed into hundreds of spaces that are built according to the image of the market and repetitiously. Those cities are far from carrying a value, identity and originality. The history of the body within the framework of the connection of cities and the history of cities show that in our century the cities have transformed into the anthropological dystopia spaces. These dystopias have collected descriptions of homo genus (such as homo saphiens, homo faber, homo ludens, and the end cyborg. The perception of time also took its share from this transformation. The time, which was a means of organizing the activities of the city until the beginning of the 20th century, was the image of a chaotic fragmentation.

In this context, the modern-postmodern city has been planned by different power structures as a large stage and showcase (shopping mall-modern market) built according to production and consumption processes. These new cities, which encircled human beings indoors and turned them into an ordinary creature that drift in crowds, led to two problem areas for future researches. The first of these is forcing people to the reinterpret of humanism's 500-year-old understanding of human, which is shaped by capitalism and confronted with gender conflict. Secondly, within the framework of new ecology (anthropocene) debates that emerged with urbanization in the 20th century, the circulation of post-humanism and transhumanism into the urban space of the viral bodies/cyborgs.

\section{Kaynakça/Reference}

Scheler, M. (1968). İnsanın kozmozdaki yeri. (T. Mengüşoğlu, Trans.) İstanbul: İstanbul Matbaasi.

Berber, Ö. (2011). Yok-yer, yersizleşme ve yersizyurtsuzluk kavramları üzerine bir sorgulama. İdeal Kent, 3, 142-157.

Şişman, N. (2013). Emannetten mülke: Kadın, beden, siyaset. İstanbul: İz Yayıncılık. Ellul, J. (1998). Sözün düşüşü. (H. Arslan, Trans.) İstanbul: Paradigma. 
Çetindoğan, M. (2009). Kırsal mitten kentsel ritüele geçiş ve beden-mekan ilişkisinin 1990 sonrası Türk oyun yazarlığı'na yansıması. Tiyatro Araştırmaları Dergisi. Tiyatro Araştırmaları Dergisi, 27 (1).

Şenel, A. (1995). Siyasal düşünceler tarihi. Ankara: Bilim ve Sanat Yayınları.

Ranciere, J. (2013). Özgürleşen seyirci. (B. Şaman, Trans.) İstanbul: Metis Yayınları (2008).

David, H. (2013). Asi şehirler. (A. Temiz, Trans.) İstanbul: Metis Yayınları (2012).

Sennett, R. (2002). Ten ve taş. (T. Birkan, Trans.) İstanbul: Metis Yayıncılık (1996).

Ullman, E., \& Harris, C. (2002). Kent doğası. (Der.) B. Duru, \& A. Alkan. 20. Yüzyıl Kenti içinde (s. 55-73.). İstanbul: İmge Yayınları.

Vitruvius. (1914). The ten books of architecture. (H. Warren, Trans.) Cambridge: Harvard University Press.

Zeller, E. (2001). Grek felsefesi tarihi. (A. Aydoğan, Trans.) İstanbul: İz Yayıncllık (1844-1852).

Benevolo, L. (1995). Avrupa tarihinde kentler. (N. Nirven, Trans.) İstanbul: Afa Yayıncilik (1993).

Bloomer\&Moore. (1977). Body, memory, and architeture. London: Yale University Press.

Aristoteles. (2013). Politika. (F. Akderin, Trans.) İstanbul: Say Yayınları.

Calvino, I. (2009). Görünmez kentler. (I. Saatçioğlu, Trans.) İstanbul: Yapı Kredi Yayınları (2002).

Corbin, A., Courtine, A. A., \& Vigarello, G. (2008). Bedenin Tarihi I. (S. Özen, Trans.) İstanbul: Yapı Kredi Yayınları (2005).

Danto, A. (2014). Sanat nedir? (Z. Barensel, Trans.) İstanbul: Sel Yayıncılık (2013).

Herakleitos. (2009). Fragmanlar. (C. Çakmak, Trans.) İstanbul: Kabalcı Yayınları.

Kleniewski, N. (2005). Cities and society. USA: Blackwell Publishing.

Jacobs, J. (1969). The economy of cities. Newyork: Vintage Book.

Lynch, K. (1960). Image of the environment. Cambridge, Massachussettes: MIT Press.

Lefebvre, H. (1991). The production of space. (D. Smith, Trans.) Cambridge: Basil Blackwell Inc.

Mumford, L. (1989). The city in history. Newyork: MJF Books.

Park, R., \& Burgess, E. (1984). The city: Suggestion for investigation of human behavior in the urban environment. London: The University of Chicago Press.

Platon. (2000). Devlet. (S. Eyüpoğlu, \& M. Cimcoz, Trans.) İstanbul: İşbankası Yayınları.

Pounds, N. (2005). The medieval city. London: Greenwood Press.

Sennett, R. (1999). Gözün vicdanı. (S. Serrabiboğlu, \& C. Kurultay, Trans.) İstanbul: Ayrıntı Yayınları (1992).

Sennett, R. (1992). The fall of public man. W.W. Norton\&Company Inc. 


\section{Yaylagül Ceran Karataş,}

İstanbul Medeniyet Üniversitesi, Edebiyat Fakültesi, Felsefe Bölümünde, Dr. Öğretim Üyesidir. Felsefi Antropoloji üst başlı̆̆ında hümanizm, posthümanizm, transhümanizm, feminizm ve çevre felsefeleri gibi çağdaş felsefe konularında araştırmalarına devam etmektedir. Dünya sürgününde öğrenciliği daim.

İstanbul Medeniyet University, Faculty of Literature, Department of Philosophy, Phd. She makes a research into philosophical anthropology, humanism, posthumanism, transhumanism, feminism, environmental philosophy in the context of contemporary philosophy. A student in the world exile.

\section{Kaynakça Bilgisi / Citation Information}

Ceran Karataş, Y. (2018). İlişkiselliğin İki Yönü: Şehir ve Beden. İDEALKENT - Kent Araştırmaları Dergisi, 24, 456-484 